\title{
Visual Literacy - A New Information-based Teaching Coordinate for the Major of Art Design
}

\author{
Yuan Yuan \\ School of Fine Art and Artistic Design \\ Guangzhou University \\ Guangzhou, China 510000
}

\begin{abstract}
Information-based teaching is one of key points to modern tertiary education development. To achieve fine visual experience is the purpose of course design for Major of Art Design. It is essential to apply digital information and communication technology to assist information-based teaching. The teaching process is not only a inventive education that based on aesthetic and logic, but also a process to guide students cognizing, estimating and creating about visual information. The paper comprises four sections: analyzation the trends of information-based teaching, definition composition elements of key competencies system, exploration of teaching method of visual literacy, and prospection of cultivating of visual literacy in the mode of Information-based teaching.
\end{abstract}

Keywords-information-based teaching; key competencies; visual literacy; teaching exploration

\section{INTRODUCTION}

The way to recognize the world begins with "seeing". It is the essential activity in which humans understand the movements of all things in the world. For a long time, visual cognition has been defined as the paradigm that mankind naturally understand and explain the world. And it is a natural physiological phenomenon. From the era of the cognitive basis of textual information to the dissemination of information in the form of graphic images, human society has gradually become the main body of information transmission. Based on images, it has completed the cognition and construction of information.

The current development of visual culture has changed the way humans perceive the world. Visual literacy highlights its importance. It guides students through an integrated visual ability developed through viewing and combining with other sensory experiences. And it promotes students to quickly acquire active and effective information from images. To properly accept, use, and create visual information is one of the essential qualities of college students.

\section{THE DEVELOPMENT OF EDUCATIONAL INFORMATIZATION PROMOTES THE OPENNESS AND INTERACTION OF TEACHING}

In the era of digital media communication, college students use books, mobile phones or online virtual teaching communities, they can touch all kinds of information-based teaching resources. This promotes the integration of teaching technology and practical teaching, and builds an effective way of learning society and education equity. The construction of education informatization has become a teaching system that supports a learning society.

China's education informatization construction began in the 1980s. This type of education is guided by modern educational theory. Modern information technology is used to develop and optimize the education process. And educational models adapted to the development of digital media and students' needs have been completed. In March 2012, the Ministry of Education has implemented a 10-year development plan for education informatization. And it has deployed an education informatization system that accelerates the development of the country's educational modernization development goals. It has built a digital campus and virtual simulation training base. And it has improved campus information. The measures such as the construction of the released digital platform have led to the modernization of education through information-based teaching and the creation of new classroom of informationbased teaching with multimedia technology.

Since the first adjoining platform was designed in Canada in 2008, all kinds of information-based teaching platforms have been rapidly promoted with its clear teaching features. After 2013, China developed a MOOCs platform organized by universities and commercial internet companies and government departments. For example, Tsinghua University, Shanghai Jiaotong University, and China Academy of Art open Moocs construction project, National Open University, NetEase Cloud Classroom and other online classroom resources. According to Coursera's data, there were 130,000 Chinese users registered on Coursera in 2013 ranking the ninth in the world. And it has reached 650,000 in 2014. In December 2016, Harvard University and MIT (Massachusetts Institute of Technology) jointly issued "Harvard x and MITx: four years of online courses". 290 
MOOC courses were opened in 4 years and the number of participants was 4.5 million. 1There are more participants in computer courses and humanities and social sciences courses in the online platform courses at this stage. The U.S. Udemy online courses are the most abundant in artistic courses. Udemy is a MOOC platform created by commercial companies and has started online education since 2010. On the website, there are more than 6,000 art courses on programming, graphic design, photography and so on. At the same time, all professional colleges and universities are also vigorously building an online classroom system. It would make the popularization of information technology teaching of art design courses develop rapidly. Also, it continuously highlights the visualization and interaction of teaching for the cultivation of innovative talents in art design. It has enriched the teaching method of art design discipline.

\section{THE DEFINITION AND CORRELATION OF VISUAL LITERACY OF ART DESIGN SPECIALTY IN CORE LITERACY SYSTEM}

Core literacy is a bridge that connects the country's education principles with teaching practices. The selection of goals reflects the latest requirements for socio-economic and technological development.

\section{A. Implementing Core Literacy Goals of Strengthening Moral Education and Cultivating People}

In 2014, the Ministry of Education issued the "Opinions on comprehensively deepening curriculum reforms and implementing the basic tasks of strengthening moral education and cultivating people". It has put forward the concept of "core literacy system" for the first time. After nearly three years of rigorous research and revision process, Chinese students' achievements in core accomplishment research were completed at Beijing Normal University. According to the national development, the students' humanistic heritage, scientific spirit, learning ability, healthy life, responsibility, and practical innovation were enhanced. And core qualities would be an important educational goal. In China's colleges and universities, the separation of subject and object of traditional art design classroom teaching mode is very popular. The students are used to passively accept professional knowledge. They lack multi-angle and dialectical ability to analyze problems. In the core literacy system, the cultivation of students' independence, creativity, and critical thinking ability is an important goal. It is an essential character and key ability that meets the needs of the society for the development of talented people and meets the needs of lifelong development and social development. Especially in the situation of the development of teaching informatization, the communication between teachers and students and the communication between students is not limited to the traditional classroom in the teaching process of art design in universities. Also, it realizes the modern teaching in a free virtual space. A lot of teaching content is

2016 was the fourth year of operation of the edX platform. In December of that year, the relevant departments of the two universities jointly published research reports according to the convention (see: http://www.caigou.com.cn/news/2017042827.shtml). transformed into "visual information". The students need to constantly think, critique and try to make decisions. And then, they could conduct self-mediated learning. The "visual information" of the art and design profession is the most significant method of teaching expression. The art and design professional classroom has become a good platform for developing core literacy education. By guiding students to understand and create "visual information" in the art design teaching, it should promote students' "visual literacy". And the students would have a healthier aesthetic value orientation, artistic expression and creative expression methods. Also, they would have the best interpretation of discovering and evaluating aesthetic awareness.

\section{B. Definition of Visual Literacy for Art and Design Major}

The study of visual literacy began early in the United States in the middle of 1960s. John Debes, the scholar was one of the most important figures in the history of the International Visual Culture Association. In 1969, Debes of Kodak's company first time defined "visual literacy". "Visual literacy" is an integrated visual capability developed by humans through viewing and combining with other sensory experiences. This is one of the prerequisites for cognitive development of human beings. People with this ability can discern various natural or artificial visual behaviors, objects, and symbols in the surrounding environment. At the same time, we can use this ability creatively to better communicate with others. By using this ability flexibly, we can gain a deeper understanding and more enjoyment of masterpieces in visual communication. 2The definition of "visual literacy" put forward by Debes was slightly modified and quoted by the International Visual Literacy Association. His definition is "basic definition". More and more countries begin to pay attention to "visual literacy" and conduct research in different disciplines. And it covers academic fields such as arts and semiotics. It involves various art design form such as image production, graphic design, costume design, and architecture. It has become a multidisciplinary and comprehensive research direction.

Each college student has different visual literacy foundations. The experience in the art design teaching process is not the same.

First of all, the students of art design majors are visual information recipients. Under the trend of informatization teaching development, the quantity of teaching materials produced by various media is huge, and the quantity exceeds the conditions that students can capture and record information. And the college students feel disordered on the pertinence and selectivity of social information. Second, under the background of popular aesthetic culture, image information tends to be entertained and commercialized. College students' visual perception of image information is more limited to the scene and experience at that time. And it is difficult to establish an overall look. Facing this strong commercial color, visual information can easily mislead students about the aesthetic perception of image information.

\footnotetext{
2 International Visual Literacy Association website:
} http//www.ivla.org_what_lit.htm. 
Third, the students of design major in the era of big data need to be good at using computers to collect, organize, and analyze super-large-scale data and information to make judgments and decisions. They are also the creators of visual information. Students of the art design profession accept the dual mission of visual image and manufacturing visual information. In the field of art design, visual thinking has gradually become an important way to grasp subject knowledge. It is a key skill to actively think about the ability of image information presented in the teaching environment. Therefore, the cultivation of visual literacy is particularly important.

\section{Visual Literacy Education in Different Regions}

The United States is the earliest country in the study of visual literacy theory and practice. Since the second half of the 20th century, the United States has developed the concept of "visual arts" and systematically promoted visual art concepts and thinking. The teaching system is aimed at different types of students. It covers visual literacy education from kindergarten education to university education and even community education. The schools in different regions have designed rich and varied teaching methods to explain the concept of visual literacy to students. And it would provide the communication of figure media resources. It would integrate visual literacy into the curriculum.

The visual literacy course at Cambridge University in the United Kingdom is unique. The teachers integrate quality training into the curriculum of children's literature research. During the teaching process, words and illustrations interact with each other to promote visual literacy. Many schools in the UK also build rich network resources and improve visual literacy education. It should build high-quality educational websites to provide rich visual cultural resources and provide students with the conditions for independent study. The UK also attaches great importance to teachers' visual literacy training. It actively carries out teacher training programs. And it actively provides learning opportunities for teachers to promote the improvement of teachers' visual literacy.

In Taiwan, it attaches great importance to the combination of culture, arts and humanities. It takes the "Arts and Humanities" curriculum, the integration of arts, music, and performing arts as the teaching basis. With the combination of information-based teaching resources, it would develop students' visual literacy.

The curricula of visual literacy in domestic universities have also been increasing in recent years. The visual culture and media literacy curriculum of Nanjing Normal University has explored the combination of visual literacy training and ethnic cultural heritage. This course has been selected as a general knowledge course. The liberal art of Nanjing Normal University was approved by information-based teaching.

\section{CONSTRUCTION OF VISUAL LITERACY TEACHING FOR ART AND DESIGN MAJORS}

Under the trend of the development of teaching informatization, the visual literacy education of art and design majors will be conducted under the guidance of visual perception theory. It will instruct art design students to have the ability to obtain visual information, and explore visual information. They would have the ability to discriminate complex visual information. And then, it would construct effective visual literacy teaching.

In visual perception theory, the relationship between visual art form and visual perception is analyzed in detail. Based on the information principle of the visible light reaching the eye discussed in visual perception theory, the human viewing process is the process of conduction to the brain to receive and identify. In combination with the characteristics of the teaching structure of the art and design major, the focus of the visual literacy teaching process is on students' abilities to develop from viewing, cognition, judgment, and creativity. Let students understand the process of visual cognition. To experience perception is the input of information. The cognitive stage is the analysis of information. The judgment stage is the choice of effective information. And creation stage is the response and execution of information.

In the teacher's instructional design process, the explicit construction of "watching" is the first step for students to perceive information. It should train students to have the willingness to acquire visual information. When they face the complex visual information, the students would have the ability to recognize the value of information. And it should guide students to simply make the transition from "looking" to the depiction of visual information. The "cognition" is the second stage of acquiring information. And it is an extremely active exploration stage. Students are encouraged to use visual information to make the selection. And short-term memory patterns are used to filter the non-meaningful information in visual information. The effective content is continuously reviewed and repeated. And learners choose to accept and judge in the cognitive process. "Judgment" is a positive reflection of information by students. In the third stage, the brain will automatically organize and receive visual information. And it should cultivate students to preserve the visual information concerned and choose positive thinking between the perception and the choice of cognition. The goal of teaching is to guide students to make innovation and creation. This stage is the positive feedback after actively recognizing information and reasonable judgments. The basis of creation is the understanding and acceptance of image information. It should train students to have creative consciousness and innovative thinking. They would be good at using the vision symbols and visual rhetoric creates visual information. It is also the key to carry out visual literacy education. And then, it would deepen the cultivation of core qualities.

\section{CONCLUSION}

The visual literacy teaching of art and design professional is not only an education based on the aesthetics and logic of innovative thinking, but also a process that guides students to accept and create visual information in a society dominated by today's visual culture. 
Under the trend of information construction in colleges and universities, visual literacy education has become an integral part of college students' art design majors. It is an important teaching content for constructing innovative teaching models and improving college students' core qualities. It is a new coordinate for innovative teaching exploration. There are many possibilities to further explore the teaching methods of college students' visual literacy training. This is a proposition that deserves deep thinking and practice.

\section{REFERENCES}

[1] [US] Paul M. Leicester. Visual Communication - Image Carrying Information [M]. Beijing: Beijing Broadcasting Institute Press, 2003 （美）保罗・ $\mathrm{M}$ ・莱斯特. 视觉传播——形象载动信息 $[\mathrm{M}]$. 北 京: 北京广播学院出版社, 2003

[2] [French] De Lucio Meyer. Visual Aesthetics [M]. Translated by Li Wei. Shanghai: Shanghai People's Publishing House, 1996 (法) 德 卢西奥 - 迈耶. 视觉美学 $[\mathrm{M}]$. 李玮译. 上海: 上海人民出版 社, 1996

[3] Zhang Shuyu. Introduction to Visual Culture. Nanjing: Jiangsu People's Publishing House, 2003 张舒予. 视觉文化概论. 南京: 江苏人民出版社, 2003

[4] Zhou Xian. Rugged Mountain Road - Cultural Critical Theory[M]. Wuhan: Hubei Education Press, 2000. 周宪. 崎岖的山路——文化批 判论集[M].武汉:湖北教育出版社, 2000 .

[5] Liu Guirong, Yan Shutao. The Philosophical and Cultural Foundation of Visual Literacy[J]. Journal of Shanxi Normal University (Social Science Edition), 2007(03). 刘桂荣, 间树涛.视觉素养的哲学文化 根基[J].山西师大学报(社会科学版),2007(03). 